\title{
KETERLIBATAN KATOLIK-TIONGHOA DI KOTA SEMARANG BAgI PANCA TUgas GEREJA
}

\author{
Hendy Kiawan a,1 \\ ${ }^{a}$ Universitas Sanata Dharma, Yogyakarta, Indonesia. \\ ${ }^{1}$ hendykiawan@gmail.com
}

Kata-kata Kunci:

Katolik-Tionghoa

Semarang

kebudayaan

masyarakat

iman

liturgi

pewartaan

\section{ABSTRACT}

The Indonesian Chinese especially in Semarang, Central Java, often experiences unfair policies. In the history of the nation's culture, they often experienced discriminations from the authorities both from the colonial government and the current regime. The Chinese are judged based on a stereotype in the economic world. Nowadays, the numbers of the Indonesia Catholic Chinese have grown enormously. The Church should provide a safe place for them to develop their faith and identity and not just use them for the economic contribution. Their role will become more strong if they are able to participate more in the five tasks of the Church. This article attempts to review the history, the hybridity, and the chance of empowerment for the Chinese in the Church.

\section{PENGANTAR}

Di balik perkembangan kota dagang yang selalu terbuka pada ilmu pengetahuan, teknologi dan jaringan ekonomi, sebagai kota pelabuhan kehidupan Jemaat di Kota Semarang pun tak bisa lepas penilaian bahwa orang Semarang terkenal berani (brangasan). Ada sebutan gertak Semarang. ${ }^{1}$ Mereka jarang menggunakan Jawa krama. Kalaupun menggunakan bahasa Jawa bisa terasa kurang halus. Orang Semarang tidak mengenal filosofi Jawa dupak kuli, esem bupati (menendang kuli, senyum bupati). ${ }^{2}$ Bagi mereka antara 'kuli' dan 'bupati' memiliki derajat yang sama. Itulah sebabnya, mereka cenderung bersifat terbuka, transparan, kurang tepa selira atau bertimbang rasa, praktis-pragmatis, dan kurang suka dengan cara yang njimet atau berputar-putar. ${ }^{3}$ Selain itu, tingkat kriminalitas di Semarang tergolong cukup tinggi. ${ }^{4}$ Karakteristik sumber daya manusia sema- cam ini pula yang menjadi bagian dalam Gereja di Kota Semarang.

Persilangan antara Gereja dan budaya yang tertuang dalam hibriditas (pendekatan sosial-kulutral) dan inkulturasi (teologi Katolik), menjadi dua kata kunci dalam tulisan ini. Jurnal ini saya dasarkan atas tesis saya dengan judul Ampyang Semarang: Membumikan Kabar Gembira dalam Katolik-Tionghoa di Semarang. Baik itu hibriditas dalam ilmu sosial maupun inkulturasi pada Gereja bukan hanya menjadi proses pembauran melainkan sarana untuk mencapai keakraban dan kemendalaman (intimacy) dalam hidup beragama dan dinamika bermasyarakat.

Dalam panggilan Gereja sebagai sakramen keselamatan di dalam Kristus (LG 1), Gereja menunaikan perutusan untuk mewartakan Kabar Gembira dalam hidup sosial, teknis, dan budaya. Masing-masing anggota Gereja yang disatukan dalam Kristus pun dipanggil untuk menjadi tanda dan sarana 
(sakramentalitas) bagi pewartaan Kabar Gembira akan keselamatan yang kelihatan. Dalam tugas membumikan Injil sebagai Kabar Gembira inilah Gereja dituntut untuk mampu 'menceburkan diri' dalam kehidupan Umat Katolik-Tionghoa Semarang secara nyata dan mendalam, mengakrabi setiap kegelisahan manusia, serta menjadi motivator mengembangkan Kerajaan Allah dalam panca tugas Gereja.

\section{SELAYANG PANDANG TIONGHOA SEMARANG}

Sebagai kota pelabuhan Semarang sendiri mempunyai kebudayaan khas dari peleburan beberapa kebudayaan yang cukup kuat yakni Arab, Jawa, Tionghoa, dan sisasisa kolonialisme Belanda. Disadari atau tidak, pribadi dengan gertak Semarangan masih kuat. Budaya gertak menjadi khasnya Semarang. Sing penting wani, salah bener urusan keri. ${ }^{5}$ Pribadi mereka terkenal brangasan. Tak mengenal tata krama seperti kaum priyayi. Bicara terus terang. Spontanitas tinggi. Kepribadian semacam ini juga ada dalam gambaran Warak Ngendog atau makhluk mitologi kebanggaan kota Semarang; kepala naga, badan buraq, kaki kambing yang melambangkan budaya Tionghoa, Arab, dan Jawa. Ada semangat ambil jarak dari kekukuhan salah satu budaya. Mereka berani melihat hal-hal obyektif terhadap liyan. Hingga akhirnya, menghasilkan unsur kebudayaan baru khas kota Semarang.

Kutub antara totok dengan baba sekarang ada perkembangan. Penampakan luarnya memang sukar dibedakan sebab keturunan Tionghoa. Namun, serta sudah amat jarang orang Tiongkok murni merantau ke Nusantara. Kini bisa dibilang mereka sama-sama peranakan. Kemenduaan totok dan baba terkait dengan feodalisme dengan warisan budaya leluhur yang di dalamnya ada bahasa, adat-istiadat, dan agama serta kekuatan emosi pada tanah Tiongkok. Keturunan Tionghoa totok tetap memegang erat budaya leluhur. Mereka menjalankan hidup doa serta perayaan budaya Tionghoa dan masih gamblang berbahasa bahkan menulis aksara leluhurnya. Lain halnya dengan baba. Baba adalah mereka yang sudah tak lagi mampu berbahasa leluhur dan tidak secara ketat merayakan tradisi dan budaya Tionghoa.

Tekanan demi tekanan terutama oleh pemerintah Hindia Belanda dan dilanjutkan oleh Orde Baru membuat etnis Tionghoa mengalami 'keterasingan bergeming' yang berdampak langsung pada identitas kebangsaan mereka. ${ }^{6}$ Bagaimana tidak, pendidikan negeri, layanan publik, serta pilihan pekerjaan di bidang industri dan perdagangan sangat terbatas. Lebih lagi pembatasan kebudayaan leluhur disingkirkan karena dicap berbau asing. Walau kelompok Tionghoa sering dihina dan disalah-salahkan namun Pemerintah Orde baru justru menyangatkan ketionghoaan. Tak peduli sejauh mana mereka sudah melakukan 'asimilasi'.

Antisipasi saling menjaga kerukunan dalam perbedaan tetap amat diperlukan di bumi Nusantara ini. Keturunan Tionghoa sendiri perlu makin cair dalam kehidupan masyarakat. Bagi elite ekonomi tinggi, perusahaan, sekat perumahan, dan kemewahan bukan menjadi menara gading yang membatasi perjumpaan dengan masyarakat sekitar. Kita tilik saudara kita yang bermukim di Gang Warung atau Gang Baru. Pelataran rumah orang-orang keturunan Tionghoa dibuat berjualan. Namun, mereka rela mengurangi kenyamanan sebab depan teras rumahnya dijadikan pasar. Hebatnya lagi, mereka malah ikut menjaga kebersihan.

Keturunan Tionghoa yang hidup di kampung memiliki cerita yang kurang lebih sama. Mereka bisa menyesuaikan diri masuk dalam kehidupan beragam dalam perkampungan. Persilangan budaya terbangun alami dalam pelajaran kehidupan. Nilai-nilai kemanusiaan. Mereka lebih mampu mengenal makna solidaritas. Tenggang rasa telah mengikat menjadi keluarga. Bahkan dari mereka dipercaya menjadi pengurus RT, RW, bahkan perangkat desa. Kiranya hal-hal positif semacam ini mampu mengukuhkan kemantapan kehidupan sosial di kota Semarang.

Sungguh menarik bila bicara soal hibriditas etnis Tionghoa-Jawa-Semarang. 
Mereka mengawalinya dari transmigrasi transnasional dan sejak dulu telah mengalami globalisasi. Fenomena persilangan terbentuk secara manusiawi akibat kontak sosial serta kebudayaan hingga terjadi penyesuaian sana-sini. Tak jarang terjadi percampuran sehingga hibritas tak hanya mengungkapkan sebagai perayaan tetapi sebuah situs yang menunjuk pada kejadian, lokasi, dan obyek; baik aktual, virtual, lampau, atau direncanakan untuk masa depan. ${ }^{7}$ Hibriditas menjadi sebuah tangga dan ruang untuk membangun identitas. Etnis Tionghoa mulanya tesebar dalam masyarakat lokal. Bertahan dalam krisis dan keterasingan. Kemudian, mereka telah menunjukkan sumbang sih untuk menghasilkan sesuatu dari buah persilangan dengan unsur kearifan penduduk setempat.

Asimililasi yang dilakukan oleh penguasa Orde Baru menjadikan orang-orang Tionghoa seperti bubur. Unsur-unsur dipaksa dicampur menjadi satu secara tergesa-gesa dengan berbagai macam aturan untuk menakut-nakuti. ${ }^{8}$ Keadaan ini tidak tepat sasaran. Membuat orang justru semakin canggung berinteraksi dengan yang lain dan justru menyangatkan stereotip khusus pada masing-masing kelompok. Proses ini menghasilkan tipe hibriditas yang kacau balau karena kurang terbuka pada pengalaman perjumpaan guna saling belajar satu sama lain serta memadukan unsur-unsur global dengan lokal dan malah saling menumbuhkan kecurigaan.

Semestinya hibriditas terjadi karena 'inisiasi' lintas budaya. Orang-orang Tionghoa di Samarang kini telah mengalami peretasan ruang dan waktu antar budaya. Boleh dikata pembelajaran tanpa disengaja atau disadari untuk membongkar identitas mereka dengan cara memberdayakan karakter, berdamai dengan tempatnya bernaung, membongkar perasaan keterasingan dari kenyamanan sebagai 'rumah dan dunianya' serta berani melampau batas-batas yang sengaja dibuat oleh 'kolonialisme' Orde Baru dan Belanda. Semangat ini dirasa sangat istimewa karena menandakan jarak relasi yang semakin dekat, menandakan kemajuan serta menjanjikan keintiman dalam persaudaraan di masa depan. ${ }^{9}$

\section{GEREJA SEBAGAI WADAH KEBUDAYAAN}

Bicara tentang keragaman dalam bangsa Indonesia, pertama haruslah disadari bahwa bukan hasil cetakan. Indonesia itu seperti mozaik. Terbentuk dari masyarakat majemuk, multigrup serta terdiri dari berbagai macam kelompok etnis. Mereka perlu paham mengenai rintangan untuk sampai kepada konsensus dikarenakan perbedaan yang sangat luas; tidak bisa dipersempit atas nama kesera-gaman. ${ }^{10}$ Meleburkan berbagai macam latar belakang suku, agama, ras dan golongan perlu dipertimbangkan lagi. Kesatuan bukan berarti kesamaan dalam berbagai sisi kehidupan yang dipersatukan dalam sejarah identitas kebangsaan Indonesia. Maka mesti diperhatikan pula kesadaran pribadi akan harkat dan martabat mengenai hak-hak asasi; baik untuk hidup, persamaan di bidang hukum, ekonomi, politik, sosial dan budaya.

Menciutkan cara pandang dengan pengkotakkan tertentu seringnya menyebabkan kesalah pahaman. Horison pengetahuan tidak bergerak pada keluasannya. Mandeg dalam keyakinan yang sulit diuji kebenarannya. Parahnya lagi jika menghasilkan radikalisme yang dieksploitasi sampai masing-masing pribadi kehilangan karakter religius. Lambat laun, harta jiwa terenggut oleh imajinasi tentang kebaikan yang terlalu dipaksakan. Yang sulit menerima atau yang berbeda menjadi musuh. Bahaya ini disadari atau tidak menjadi bagian dalam perkembangan Indonesia. Isu SARA merupakan senjata penggerak massa agar melawan liyan. Kalau tidak hati-hati terciptalah intoleransi. Masing-masing kelompok membentuk persekongkolan untuk saling melawan. Maka, manusia perlu dibawa pada kesadaran akan nilai nasionalisme. ${ }^{11}$

Manusia menuju kepenuhannya yang sejati melalui kebudayaan. ${ }^{12}$ Melalui akal budi, hati nurani, dan kebebasannya, manusia bisa mengatasi situasi keadaan lingkungan dan zamannya. Sejatinya manusia dipanggil untuk bertanggungjawab terhadap kelestarian semesta; termasuk memper- 
hatikan pula sesama manusia dan lingkungannya. Ini salah satu bagian hidup manusiawi yang tak lepas dari kebudayaan. Sudah semestinya, arahan manusia mendayagunakan keutuhan diri sebagai sarana untuk merawat kehidupan.

Gereja sedemikian sadarnya terhadap keberagaman budaya ini. Gereja berisi kumpulan manusia yang tak bisa lepas dari kebudayaannya. Maka, ia membutuhkan penunjang dengan berbagai macam ilmu pengetahuan yang secara khusus mampu mengungkapkan sekaligus menjelaskan perikehidupan manusia dari sisi antropologi dan sosiologis. Sisi humanisme Gereja haruslah nampak sehingga sangat tepatlah bila dalam melaksanakan tugas perutusannya, Gereja pun perlu mempelajari disiplin ilmu demi menjaga kesatuannya dengan manusia dari berbagai macam kebudayaan termasuk peri kehidupan. ${ }^{13}$ Ini juga berlaku bagi orang-orang KatolikTionghoa Semarang dalam kesatuannya dengan Gereja khususnya Gereja Keuskupan Agung Semarang.

Pentinglah kebijaksanaan dalam memainkan ketegangan antara iman Kristiani dan tradisi ketionghoaan dalam menjalankan salah satu reksa pastoral Gereja. Yang diidealkan dengan inkulturasi, baiknya masuk dalam keluasannya; tidak hanya bidang liturgi semata melainkan kelima panca tugas Gereja. Seraya berpegang teguh pada tradisinya sendiri dan menyadari karya perutusan lebih universal, Gereja menjalin persekutuan dengan pelbagai pola kebudayaan termasuk budaya Tionghoa di Semarang; tentu penghayatan tradisi orang-orang Tionghoa pun beragam sesuai dengan konteks daerah tertentu. Bagaimanapun, pokok pewartaan tentang Kristus sebagai Kabar Baik yang mengangkat martabat manusia berdosa, melawan, memberantas kesesatan-kesesatan serta kemalangan akibat dari bujukan dosa menjadi pokok pewartaan Gereja sembari menjernihkan dan mengangkat adat-istiadat para bangsa. Berikut saya ungkap tentang upaya

\section{Pewartaan (Kerygma) pada Hibrida Katolik-Tionghoa di Semarang}

Identitas Tionghoa di Semarang yang hidrid -dengan beragam penyesuaian, pencampuran aneka budaya serta perkembangan zaman- menuntut Gereja agar lebih kreatif membumikan Kabar Gembira di tengah Umat-Katolik Tionghoa Semarang. Inilah bagian dari tugas kerygma. ${ }^{14}$ Secara singkat, kerygma berarti pewartaan akan Yesus Kristus (Rm 13:25), Dialah Sang Sabda Allah yang menyelamatkan dunia. Pokok pewartaan Gereja adalah Kabar Gembira atau Injil yang mengajak dan memanggil siapa saja untuk mendengarkan serta menerima Yesus Kristus. ${ }^{15}$

Umat Katolik-Tionghoa Semarang tampak lebih longgar dalam menyikapi budaya lelu-hur mereka. Sebagian besar generasi muda malah tak begitu menghiraukan tentang akar budaya Tionghoa. Mereka hanya mengenal Imlek dan Cap Go Meh sebagai hari besar budaya. Beberapa dari mereka masih merayakan Ceng Beng. Sedang yang lainnya, seolah tak ada kepedulian khusus menaruh minat pada budaya leluhur mereka. Orang tua mereka pun tidak menyalahkan mereka seperti itu.

Rumah-rumah orang Katolik Tionghoa Semarang kebanyakan sudah tak tampak lagi arsitektur Tionghoa. Semarang makin padat. Zaman dulu, orang Tionghoa gemar tinggal di rumah yang tembus sungai, jalan, ngantong (seperti trapesium; tampak kecil dari depan tapi melebar jika sudah masuk), dan terdapat ornamen khas Tiongkok. Sekarang, lebih cenderung menyesuaikan dengan arsitektur modern. ${ }^{16}$ Sudah tak banyak orang Tionghoa mempunyai altar sebagai wujud penghormatan terhadap leluhur apalagi altar dewa-dewi. Dengan demikian, upacara penghormatan dewadewi sudah tak dilangsungkan lagi. Bagi generasi tua yang mengikuti anaknya memeluk agama Katolik biasanya menyerahkan patung-patung dewa-dewi ke klenteng. Sebagian menyimpan tapi sudah tidak untuk sembahyang. 
Upacara Ceng Beng (atau hari raya Qiming) ini merupakan salah satu bagian dari kesakralan tradisi Tionghoa. Konon dipercaya bagi para petani agar roh nenek moyang dan para leluhur ikut menjaga sekaligus merestui apa yang ditaman setelah upacara Cap Go Meh. Lebih luas lagi, untuk keseluruhan orang Tionghoa, upacara Ceng Beng ini merupakan salah satu bakti yang nyata terhadap para leluhur. Mereka sangat percaya bahwa roh-roh nenek moyang tetap akan terus berkarya membantu orang-orang yang masih hidup di dunia. Jika tidak diperhatikan dengan cara membersihkan makam -bisa pula menghormati abu leluhurdan mengirim sesaji untuk mereka akan menimbulkan malapetaka terutama dalam usaha mereka karena ada pandangan bila arwah tidak didoakan dan akan menjadi arwah yang jahat. ${ }^{17}$

Pada dasarnya, keyakinan religius orang Tionghoa termasuk religi 'baur'. Dikatakan demikian karena teologi, ritual dan organisasi kependetaannya membaur menjadi satu dan integral dengan konsep dan struktur masyarakat. ${ }^{18}$ Ini tidak sama dengan sistem religi institusional seperti Katolik dan agama-agama semitik lainnya. Perilaku dan tindakan sehari-hari 'dilakukan dengan' dan 'berdasar kepada' yang adikodrati. Leluhur klasik Tiongkok menganut shenisme; religi politeistik dan eklektik (memilih yang terbaik dari berbagai sumber) kemudian mengintegrasikannya pada pemujaan terhadap shen atau arwah.

Sebuah tantangan besar bagi Gereja untuk mampu mengakrabi simbol-simbol orang Tionghoa dan tradisi ketimuran lainnya melalui cara pandang dan pemikiran teologi 'Barat' terutama pada adat yang berkaitan dengan paham keselamatan. Satu sisi menunjukkan kepatuhan agama-agama lain dan budaya dipandang sebagai benihbenih sabda dan persiapan sejati bagi Kabar Gembira yang kepenuhannya ada pada Kristianitas. ${ }^{19}$ Sisi lain yang perlu ditempuh Gereja -terutama Gereja Asia- ialah dengan dialog pertukaran nilai-nilai sebagai wujud Evangelisasi. Penyebaran Warta Gembira bukan propaganda melainkan masuk dari sisi eksistensial dan aktual dalam masyarakat. ${ }^{20}$

Selanjutnya dari sisi perayaan hari besar, tentu salah satu acara tahunan yang sangat dinanti bagi masyarakat Tionghoa adalah Imlekan. Tahun baru selalu memberi suasana gegap gempita. Di Semarang, imlek juga sangat meriah. Pusat perbelanjaan, kantor, serta beberapa tempat umum diberi aksen merah. Tak luput ornamen khas Tiongkok dan pernak-pernik shio tahun baru. Kegembiraan Imlek tidak hanya dirasakan pula oleh orang-orang Tionghoa saja, melainkan juga masya-rakat Indonesia pada umumnya. Misalnya di Semarang, jaringan Kopi Semawis menyelenggarakan Pasar Imlek selama tiga hari yang menjajakan aneka kuliner, hiasan-hiasan khas Tiongkok, serta pentas budaya. Tentu keramaian ini menjadi destinasi wisata baik lokal, nasional bahkan internasional.

Imlek dihitung menggunakan kalender bulan (lunar) yang sangat tepat untuk pekerjaan di bidang pertanian. Kaum petani -golongan mayoritas di Tiongkok- tentu masih menggunakannya sekalipun dilarang keras. Mereka masih tetap merayakan peringatan ini sebagai 'pesta musim semi'. Tidak ada alasan untuk tidak bergembira karena rakyat beranggapan bahwa mereka telah hidup kembali. Mereka -seolah-olah mati pada musim dingin yang gelap dan suram-, saat tahun baru Imlek, ada jiwa dan semangat baru untuk memulai kehidupan. ${ }^{21}$

Beberapa tradisi klasik masih menjalankan doa kepada Dewa Dapur dan Sembahyang Teh menjelang Imlek. Peringatan Tahun Baru ini menjadi sarana yang baik untuk ngumpulke balung pisah ${ }^{22}$ (pengumpulkan tulang yang tercerai-berai). Di dalam rumah biasanya mereka saling memberi hormat. Urut dari yang muda ke generasi tua dengan soja (tradisi lama; dengan cara bertiarap) atau sungkem. ${ }^{23}$ Setelahnya ada sembahyang keluarga untuk mendoakan para leluhur ${ }^{24}$ dan dilanjutkan jamuan makan bersama. Esok hari juga ada sembahyang pagi, baru setelahnya berkeliling untuk silaturahmi. 
Malam ke delapan setelah Hari Raya Imlek, orang Tionghoa melakukan sembahyang Tuhan Allah yang familiar dipanggil King Thi Kong sekaligus turunnya kembali Dewa Dapur ke rumah-rumah. Rangkaian Imlek ditutup dengan perayaan Cap Go Meh yakni 15 hari setelah Imlek. Selain sembahyang bersama -awalnya dulu untuk memulai musim taman- diselenggarakan beberapa festival atau pesta rakyat. $^{25} \mathrm{Di}$ Semarang tak luput dari keramaian ini. Orang-orang Tionghoa menyediakan lontong Cap Go Meh. Hebatnya lagi, ada tradisi munjung (memberikan hidangan kepada tetangga, saudara, atau kolega sebagai pesta bersama).

Gereja Katolik di Semarang mengakomodasi Umat Katolik-Tionghoa yang merayakan Ekaristi Tahun Baru Cina yang gamblangnya disebut Misa Imlek (lih. Bagian "Gado-gado dalam Liturgi" di bawah). Misa ini sangat meriah dan dinanti. Umat Tionghoa biasanya menyediakan angpaw dan bingkisan imlek kepada jemaat yang hadir. Misa imlek ini menjadi perayaan bersama Gereja dan bukan eksklusif bagi orang-orang Katolik-Tionghoa saja yang hadir di perayaan itu. Memang perlu ada beberapa garis besar yang perlu diperhatikan supaya ungkapan syukur Imlek ini sejalan dengan ranah iman Kristiani.

Dalam perjalanan hidup, orang Tionghoa juga mengenal ruwatan. Upacara ini disebut Ciswak. Inilah ruwatan ala Tionghoa. Bahasa aslinya dari zhi sha. ${ }^{26}$ Artinya sembahyang untuk menolak yang jahat termasuk bencana alam serta keburukan-keburukan lain. Orang Tionghoa percaya bahwa ketidakseimbangan Yin-Yang akan menghasilkan malapetaka. Yang dibutuhkan adalah kembali pada keselarasan ruang dan waktu dengan konsep san cai atau tiga penyeimbang meliputi langit, bumi, dan manusia. Upacara Ciswak intinya meminta kepada Yang Maha Tinggi untuk memberkati serta melindungi umat-Nya.

Yang menjadi pokok kerygma bagi Umat Katolik-Tionghoa ialah bicara soal karya keselamatan. Gereja mengimani bahwa penyelamatan terjadi pada karya Allah Tritunggal. Keyakinan bahwa Allah Bapa menyelamatkan manusia di dalam Kristus oleh Roh Kudus. Ini tertuang dalam aksioma dasar Teologi Kristiani. Karya keselamatan itu sudah berlangsung dalam sejarah manusia secara konkret dan menyejarah. Allah sudah menetapkan rencana keselamatan dalam Kristus sejak semula. Dipuncaki pada misteri sengsara, wafat dan kebangkitan Kristus dan diteruskan oleh Roh Kudus sampai pada kepenuhan karya keselamatan itu di akhir zaman.

Misteri Allah Trinitas pada orang Kristinai berbeda dengan kepercayaan Tionghoa klasik, khususnya mengenai pribadi-pribadi Adi-kuasa. Bagi orang-orang Tionghoa perantauan yang hadir di Semarang, mereka pun meyakini kehadiran dewa-dewi. Ketika datang di tempat yang baru, mereka mendirikan klenteng untuk menghormati dewa-dewi yang sudah berjasa melindungi mereka. Dari klenteng itulah, orang-orang Tionghoa meminta pertolongan dari pribadi Adikuasa untuk membantu setiap masalah kehidupan misalnya rejeki, sakit, jodoh dan lain sebagainya. Ada personifikasi pribadi yang mereka rasa agung karena sistem 'religi baur' dalam shenisme. ${ }^{27}$ Pribadi-pribadi Adikodrati tersebut mereka rasakan aktif ikut serta dalam kehidupan manusia bahkan ikut ambil bagian dalam pranata-pranata sosial. Tak segan dalam rumah pribadi mereka mempunyai altar khusus untuk sembahyang dan berdevosi kepada mereka.

Melalui Sakramen Baptis, Umat Tionghoa telah menjadi Katolik. Pembaptisan ini merupakan kelahiran dan hidup baru di dalam Kristus. Rahmat baptis ini membuka tiga rahmat penting yakni; pertama, pengampunan dosa asal serta semua dosa pribadi maupun hukuman dosa; kedua, kelahiran dalam hidup baru yang membuat manusia menjadi 'ciptaan baru' yakni diangkat menjadi anak-anak Allah dan boleh ambil bagian dalam kodrat ilahi, anggota tubuh Kristus dan ahli waris bersama dengan Dia, serta kenisah Roh Kudus, dan ketiga, menjadi anggota Gereja. Rahmat baptisan ini mengikat kuat dan memungkinkan seseorang untuk percaya akan Allah, berharap pada-Nya, dan menga- 
sihi-Nya berkat keutamaan teologal, hidup di bawah bimbingan Roh Kudus, berbuat berkat karunia Roh, serta berkembang dalam kebaikan berkat keutamaan moral. ${ }^{28}$

Sebuah tanggung jawab besar bagi para teolog dan klerus yang notabene menjadi gembala sekaligus seorang religius untuk menjelaskan sisi soteriologi yakni ilmu mengenai keselamatan. Yohanes Paulus II menekankan pentingnya sisi pribadi manusiawi (persona humana) pada budaya yang masuk ke dalam orbit keselamatan Kristus bagi Umat manusia. Untuk menjelaskan mengenai sisi keselamatan terhadap orang Katolik-Tionghoa di Semarang, mereka perlu membaca dengan jeli sisi etis, aksiologis (teori tata nilai), dan dimensi institusional Gerejani. Hakikatnya, para klerus, teolog, serta katekis awam menjadi jembatan untuk menerangkan sekaligus memberi penilaian akan kesinambungan antara Gereja sebagai lembaga (organisasi) sekaligus menjadi perkumpulan orang-orang yang hidup (organisme). ${ }^{29}$

Pokok terpenting berkatekese adalah mengakui pokok-pokok ajaran iman Kristen seperti yang tertuang pada syahadat para rasul. Berkaitan dengan praktek tradisi leluhur yang masih berlangsung dalam diri beberapa Umat Katolik-Tionghoa, tentu menjadi keunikan tersendiri. Mereka tentu sudah mempertimbangkan nilai-nilai kristiani. ${ }^{30}$ Walau mereka tetap mengikuti beberapa tradisi leluhur akan tetapi masih dalam koridor iman Kristiani. Mereka tetap menghormati leluhur, berdoa untuk keselamatan jiwa mereka, bahkan memberi sesaji kepada para pendahulu sebagai wujud pengenangan yang lebih dalam maknanya dari memberi makan roh. Beberapa yang masih punya patung-patung dewa-dewi Tiongkok telah dititipkan di klenteng. Kalaupun ada yang masih memiliki, biasanya diletakkan di samping foto leluhur karena pendahulu lebih dulu mengenal pribadi-pribadi Adikuasa berupa personifikasi dewa-dewi sebelum sekarang mereka mengenal Yesus. Jadi lebih mendekatkan leluhur pada figur penolong yang mereka dekat semasa hidup dan tidak untuk berdoa.

\section{Koinonia: Dinamika Katolik-Tionghoa Mewujudkan Persaudaraan}

Umat beriman Kristiani disemangati oleh roh Gereja Perdana bertekun dalam pengajaran Para Rasul dan dalam persekutuan. Mereka berkumpul untuk memecahkan roti dan berdoa (Kis 2:42). ${ }^{31}$ Maka, membangun persekutuan adalah salah satu tugas Gereja yang disebut koinonia. ${ }^{32}$ Allah memanggil manusia menuju keselamatan bukan hanya sebagai individu melainkan juga sebagai bagian dari seluruh Umat. Gaya hidup individualistik dewasa ini telah mengguncangkan makna persekutuan. Menyikapi hal ini, Gereja perlu berusaha mengajak Umat untuk saling menghargai, mengasihi, dan menolong. ${ }^{33}$

Kekhasan Gereja sebagai persekutuan telah nampak dalam namanya. Ditinjau dari etomologi kata, Gereja berasal dari bahasa Portugis igreja; kata ini merupakan turunan dari bahasa Yunani ekklesia ${ }^{34}$ yang berarti 'rapat rakyat', 'perkumpulan rakyat' dan dalam konteks keagamaan bermakna perkumpulan orang-orang beriman. ${ }^{35}$ Kata ekklesia sendiri merupakan bentukan dari dua suku kata yakni $e k$ (ke luar) dan kalein (memanggil). Keunikan panggilan sebagai persekutuan terlihat saat tiap-tiap pribadi meninggalkan urusan mereka masing dan berkumpul bersama untuk tujuan tertentu.

Jika saya perhatikan berdasarkan pengalaman berdinamika dan perjumpaan dengan Umat Katolik di Semarang, akar dari masalah Gereja di Semarang adalah eksklusivitas baik itu personal maupun golongan. Banyaknya komunitas dan kelompok kategorial dalam jemaat ${ }^{36}$ bisa menjadi sumber daya utama bagi Gereja dan memancing kreativitas pastoral untuk para pemimpin jemaat. Akan tetapi, kadang kala terjadi eksklusivitas dalam kelompok sehingga satu dengan yang lain terdapat gesekan. Beberapa dari mereka loyal terhadap kelompoknya dan lupa bahwa kehadiran kolompok-kelompok kebangunan rohani dan kategorial ini berada dalam kesa-tuan dengan Gereja sebagai koinonia. 
Hal lain yang menjadi masalah dalam membangun Gereja di tengah kepelbagian kota Semarang adalah masih adanya stereotip di akar rumput. Menyikapi hal ini, Gereja harus menjadi promotor sekaligus motivator dalam membongkar cara pandang yang lama dengan penuh rasa curiga untuk memandang sesama. Gereja perlu mempertimbangkan aspek perjumpaan yang menjadi sarana untuk menumbuhkembangkan kasih dan persaudaraan multi dimensi, kultural, dan lintas agama. Semangat ini bisa ditampakkan dari penyusunan program kerja dan acara Gereja dalam komunitas basis teritorial -lingkungan, wilayah, paroki dan keuskupan- maupun kategorial.

Idealnya, Gereja bergerak dalam dua matra: teritorial dan kategorial-fungsional maupun patembayan-organisasional dan paguyuban atau communio. ${ }^{37}$ Satu sisi memang perlu kepatuhan terhadap teritorial -keuskupan, kevikepan, paroki, wilayah, lingkungan sampai ke blok-blok- dengan segala wewenang dan pranata layannya, sisi lain dalam matra kategorial-fungsional, Gereja mempunyai kewajiban untuk merengkuh Umat yang serba terpencar secara teritorial namun menyatukan dalam satu kelompok berdasarkan kategori atau fungsi tertentu. Sebagai organisasi adalah baik untuk mengurusi tata administrasi yang mengedepankan efisiensi dan efektivitas dalam berpastoral. Akan tetapi, beripijak dari kehidupan Jemaat Korintus, Gereja memperhatikan pula roh paguyuban yang menekankan keluwesan dan perkembangan karisma-karisma di tengah Umat. Dengan mengedepankan dialog, keterbukaan dan sinergi antar karisma dibutuhkan untuk membangun 'Gereja muda' yang dinamis dan tak tergerus oleh zaman.

Pemahaman mengenai koinonia memang bertitik tolak pada persatuan di dalam Gereja. ${ }^{38}$ Akan tetapi, penghayatan persekutuan tidak berhenti di sini. Siapupun yang memasuki persekutan dengan Tuhan, diharapkan menghasilkan buah: 'Barangsiapa tinggal di dalam Aku dan Aku di dalam dia, ia berbuah banyak (Yoh 15:5). Dalam arti itu, persekutuan dan perutusan mempunyai kaitan yang tidak bisa dilepaskan.
Keduanya saling merasuki dan merangkum sehingga persekuan menyajikan sumber dan buah hasil perutusan. Persekutuan membangkitkan perutusan dan perutusan terlaksana dalam persekutuan. ${ }^{39}$

Dalam Gereja di Asia -Anjuran Apolostik Pasca Sidang Istimewa Sinode Uskup di Asia yang berlangsung di Vatikan tanggal 18 April hingga 14 Mei 1998- ini, Paus Yohanes Paulus II begitu menekankan pentingnya persatuan di dalam Gereja dalam semangat persekutuan dan kolegialitas. ${ }^{40}$ Gereja-gereja setempat -yakni keuskupan- menampakkan diri sebagai persekutuan jemaat-jemaat (communio communitatum). Para anggota Gereja -menyangkut klerus, para anggota hidup bakti atau biarawan dan biarawati, dan Umat awam- melibatkan diri dalam 'dialog kehidupan dan hati' yang ditopang oleh Roh Kudus. ${ }^{41}$ Dalam keuskupan inilah visi tentang persekutuan jemaat-jemaat dapat diwujudkan di tengah kenyataan sosial, politik, religius, budaya dan ekonomi yang kompleks di Asia. Hal ini diwujudkan dengan adanya Gereja partisipatif. Di dalam Gereja, Umat Allah dapat menghayati panggilan dan melaksanakan peran mereka yang khas sesuai dengan karisma dari masing-masing pribadi untuk membangun 'persekutuan bagi perutusan' dan 'perutusan persekutuan'. ${ }^{42}$

Kecanggungan untuk membuka diri dalam komunitas yang nyata -baik di Gereja maupun masyarakat- mulai menggeroti roh paguyuban. Keseimbangan antara hidup religius, sosial dan entreprenuership seperti yang digagas oleh pendiri Semarang, Ki Ageng Pandanaran, ada kalanya mengalami ketimpangan. Sejauh yang saya amati, penyebabnya ada beberapa faktor. Pertama, kenyamanan dan keasyikan berada dalam diri sendiri dan kelompok. Kedua, timbulnya prasangka yang seolah-olah mengancam diri dan orang-orang 'terdekat'. Ketiga, merasa kehabisan waktu dan tenaga atau dengan kata lain tidak menempatkan bidang paguyuban dalam prioritas hidup. Terakhir, pengaruh sosial media, sarana prasarana teknologi, dan merasa cukup dengan dinamika masa melalui telepon pintar. Keempat hal ini yang mengakibatkan sikap 'emoh' 
pada paguyuban baik di masyarakat dan Gereja.

Dalam upaya menggiatkan 'pemberdayaan kaum awam', Gereja Keuskupan Agung Semarang mengundang setiap pribadi agar ikut ambil bagian dalam peran dan fungsi Gereja. Pemberdayaan dipilih sebagai model dengan tujuan utama untuk memperkuat daya tampung dan daya serap atau kapasitas subyek supaya lebih mampu mandiri dalam menentukan hari depan mereka tanpa tergantung dari pihak lain dengan lima aspek utama yakni pemenuhan kebutuhan dasar, peningkatan akses penunjang kesejahteraan, peningkatan kapasitas mengorganisasi diri, pendidikan kritis dan penguatan kontrol sosial. ${ }^{44}$ Umat KatolikTionghoa mestinya dilibatkan dalam program mulia ini sesuai dengan kemam-puan dan pengalaman hidup mereka masingmasing.

Pengembangan makna persekutuan jemaat oleh Keuskupan Agung Semarang ditegaskan dengan frasa persekutuan paguyuban-paguyuban Yesus Kristus. ${ }^{45}$ Gereja Keuskupan Agung Semarang pun menegaskan model Gereja sebagai paguyuban sebagai model persekutuan jemaat. ${ }^{46}$ Kata 'paguyuban' menunjukkan terobosan inkulturatif dari bahasa Jawa untuk menekankan roh persaudaraan, solidaritas, serta keintiman relasi personal dalam membangun kehidupan bersama. Kata paguyuban dikontraskan dengan patembayan yang menekankan relasi organisatoris, hierarkhis, dan birokratis. $^{47}$

\section{‘Gado-gado’ dalam Liturgi}

Sebagaimana yang tertuang dalam Konstitusi tentang Liturgi Suci (Sacrosanctum Concilium), dalam hal-hal yang tidak menyangkut iman atau kesejahteraan segenap jemaat, Gereja dalam liturgi pun tidak ingin mengharuskan suatu keseragaman yang kaku. Gereja memelihara dan memajukan kekayaan yang menghiasi jiwa pelbagai suku dan bangsa (SC 37). Gereja membuka diri dengan lebih murah hati terhadap adat kebiasaan para bangsa juga terhadap budaya orang-orang Tionghoa. Catatan resmi dari Gereja untuk diper- hatikan menyangkut dua hal yakni kesatuan dengan hakikat semangat liturgi Gereja dan sesuai iman Katolik; tak terikat pada takhayul atau ajaran-ajaran menyimpang.

Gereja menghimbau kepada para pemimpin gerejawi setempat untuk lebih tekun dan bijaksana dalam mempertimbangkan unsur-unsur manakah dari tradisitradisi dan ciri khas masing-masing bangsa yang dapat ditampung dalam ibadat ilahi (SC 40). Dari rumusan ini, kita dapat melihat keluwesan Gereja memberi peluang untuk memasukkan tradisi dan nilai-nilai budaya Tionghoa dalam liturgi Gereja. Liturgi sendiri arti dasariahnya ialah pelayanan yang dibaktikan bagi kepentingan manusia. ${ }^{48}$ Selanjutnya dalam Gereja Katolik, liturgi dimengerti sebagai upacara atau ibadat publik Gereja. Supaya tidak menjadi batu sandungan dalam mempraktikkan inkulturasi liturgi, pertama-tama kita perlu memperdalam makna liturgi Gereja terlebih dahulu barulah mencari titik penyesuaian-penyesuaian yang dapat menyemarakkan penghayatan iman Umat KatolikTionghoa dalam liturgi Gereja.

Memang belum ada teks khusus yang mengulas secara menyeluruh tentang pandangan Gereja secara resmi untuk menyikapi ritus dan tradisi Tionghoa. Dari pembicaraan para uskup Taiwan dengan Monseigneur Joseph Caprio tertanggal 18-19 Juli 1964 tentang Penghormatan Leluhur, diperbolehkan mengenang orang tua atau leluhur dengan menyediakan plakat berisi nama orang yang meninggal tapi tanpa tambahan tulisan yang berbau takhayul. Mereka pun diizinkan memberi penghormatan di depan plakat, foto, atau peti mati serta menyediakan buah atau makanan di depan plakat leluhur atau di kubur. Yang tidak diperkenankan adalah membakar uang kertas bagi jenazah sebab dianggap takhayul. Penggunaan hio, bukanlah untuk menghormati orang yang sudah meninggal melainkan Allah yang Maha Tinggi. Jika orang KatolikTionghoa merasa kebingungan melihat tradisi dan adat istiadat Tionghoa dalam kacamata iman Kristen, perlulah datang kepada imam supaya tidak menjadi batu sandungan. ${ }^{49}$ 
Liturgi dalam Gereja sangatlah luas. Tidak terbatas pada ekaristi saja. Ada liturgi sakramen (menyangkut 7 sakramen Gereja, liturgi sabda, dan liturgi harian atau ibadat harian). Dalam kaitannya dengan budaya Tionghoa, Gereja telah terbuka menerima andai saja budaya Tionghoa masuk dalam ruang lingkup liturgi. Beberapa penyesuaian dimungkinkan terjadi terutama mengenai perayaan sakramen-sakramen, sakramentali, perarakan, bahasa liturgi, musik Gereja dan kesenian-kesenian khas Tiongkok (SC 39). Penyesuaian ini bisa dilakukan dengan izin dari Tahta Suci, Uskup, Konferensi para Uskup, atau imam (SC 22).

Selama ini, Gereja Keuskupan Agung Semarang memberi keleluasaan untuk melangsungkan liturgi dengan cita rasa Tiongkok. Yang tampak dan menjadi tradisi adalah melangsungkan Misa Imlek. Parokiparoki yang merasa mempunyai Umat Tionghoa yang cukup banyak umumnya menyelenggarakan Misa Imlek saat tahun baru Tionghoa. Ini juga berlaku di Semarang. Beberapa paroki cukup meriah dalam menyelenggarakan misa ini. Biasanya saat perarakan dengan Barongsai dan tariantarian khas Tiongkok. Ada punya yang menggunakan lantunan musik erhu, kecapi, dan lain-lain sebagai pengiring lagu-lagu Ekaristi. Lampion-lampion, bunga, serta hiasan-hiasan etnik Tiongkok menambah gemerlapnya suasana Gereja. Imamnya mengenakan warna liturgi merah bahkan ada pula yang mengenakan topi kekaisaran klasik. Demikian umatnya didominasi berbusana merah. Tak lupa pula, ada pembagian angpau dan bingkisan imlek yang isinya jeruk, kue ranjang, manisan, atau pun yang lain. Seperti inilah gambaran yang disebutkan dengan misa ikulturasi dalam mana budaya Tionghoa masuk dalam liturgi Gereja.

Penting bila melihat lebih dalam soal inkulturasi. Istilah inkulturasi hendaknya tidak hanya dipahami dalam kasanah misa saja seolah sebuah prestasi seandainya bisa memasukkan unsur-unsur budaya misalnya budaya Tionghoa dalam misa. Bidang inkulturasi haruslah ditelakkan dalam keluasannya. Hal ini menjadi bagian dari misi
Evangelisasi agar Injil menjadi daya yang mengilhami, membentuk, serta memberi daya ubah. Lebih dari 'luaran', inkulturasi perlulah mengungkapkan iman Kristiani dalam terang misteri Paskah yang menjiwai hidup sesorang dalam hidup konkretnya sehari-hari. ${ }^{50}$

Perayaan iman dan kebudayaan merupakan proses kesalingan. Mestinya yang terjadi dalam orang Tionghoa yang telah memeluk agama Katolik, perayaan iman merayakan iman terjadi di dalam kebudayaan dan merayakan kebudayaan di dalam iman. Seyogyanya keduanya dapat berjalan secara beriringan. Yang saya bahas di sini bukanlah pendekatan supaya orang-orang Tionghoa dapat menjadi Kristen, melainkan lebih bagai-mana orang-orang Tionghoa dapat merayakan iman Kristiani sekaligus kebudayaan dengan pemahaman yang sekiranya sejalan dengan cara pandang Gereja.

\section{Martyria dalam Dialog Gereja Asia}

Jika kita berbicara tentang kemartiran, terbesit dalam benak kita para santo-santa atau orang-orang yang rela mati untuk mempejuangkan iman. Pandangan itu tidak keliru tapi perlu disesuaikan dengan zaman. Martyria berasal dari bahasa Yunani yang artinya kesaksian. Kata ini menunjuk pada bidang hidup atau pelayanan Gereja yang berpusat pada kesaksian untuk masyarakat baik lewat kata-kata maupun terutama lewat karya nyata. ${ }^{51}$ Saat jemaat Kristen mengalami penganiayayan, kesaksian ditunjukkan dari keteguhan hati mempertahankan iman bahkan hingga mengorbankan diri bahkan sampai mati. Makna kemartiran dipersempit dalam frasa penumpahan darah demi iman.

Akan tetapi di zaman modern ini, makna martyria perlu dikembalikan pada keluasannya yakni kesaksian tentang karya keselamatan Yesus Kristus yang 'sudah' dan 'belum' terjadi. Kata ‘sudah' menunjuk pada misteri inkarnasi dan dipuncaki pada peristiwa Paskah di mana Yesus Kristus yang telah berkurban bagi seluruh mahkluk dan bangkit dari antara orang mati. Karya keselamatan Kristus ini 'belum' berakhir hingga kedatangan Kristus kedua kali. Dalam masa 
penantian Kristus ini, Gereja sebagai pelayan keselamatan bagi dunia bertanggungjawab untuk mengkonkretkan iman dalam sejarah dan masyarakat secara historis, kontekstual, fungsional, terbuka kepada dunia, dan membiarkan dunia ambil bagian dalam menyusun aturan hariannya. ${ }^{52}$

Gereja bergerak dalam arus zaman yang deras akan tantangan salah satunya isu rasionalitas. Sebuah kiritikan tajam bahwasanya figur Allah dikatakan sebagai sumber ketakutan dan agama menjadi sarana 'menghasut' seseorang untuk bereaksi negatif terhadap mereka yang tidak sepaham. Oleh karenanya, iman harus mampu dipertanggungjawabkan dengan akal budi manusia. Konsep beriman bukan melulu 'keyakinan tanpa pertanyaan' melainkan bagaimana menjelaskan isu religius dengan akal sehat. Kalau tidak mampu demikian, lembaga keagamaan akan jatuh pada sikap keras kepala melahirkan generasi fundamentalis. Produknya tidak lain akan melahirkan kekerasan dan tragedi. ${ }^{53}$

Beberapa cara telah dilakukan Gereja untuk menyapa setiap manusia dalam keberadaan mereka di dunia. Gereja Universal membuka peluang pada Gerejagereja lokal (Ecclesiae particularis) untuk merefleksikan teologi secara kontekstual untuk menjawab kebutuhan iman Umat setempat. Tahap pertama ialah penerjemahan. Tahap ini merupakan tataran untuk membebaskan pesan Kristiani dari kandang budaya sebelumnya kemudian memungkinkan penerjemahan dalam situasi baru seperti penerjemahan alkitab dan kosakata teologi. Kedua, adalah adaptasi dengan menggunakan dasar-dasar ilmu sosial dan filsafat Barat untuk menjelaskan kesatuan (integritas) tradisi kerasulan Gerejani dengan tradisi budaya setempat. Ketiga adalah metode kontekstual yakni dengan menyelami budaya setempat. Gereja berani mengkaji etnologi dan memusatkan pada dinamika sosial serta sejarah guna merefleksikan iman secara sistematis untuk menggerakan semakin banyak Umat lokal dalam merayakan iman mereka. ${ }^{54}$

Gereja Katolik Asia lebih menukik tajam dalam membahasakan misi dalam memba- ngun teologi lokal dengan kata dialog. Sebagai manusia, kita tak pernah lepas dari kegiatan bersoal jawab mengenai kehidupan. Lebih-lebih dalam konteks Gereja Asia. Upaya ini digunakan Gereja sebagai way of life dalam menyelami dinamika Asia yang multikultur karena dalam etnologi, setiap generasi memiliki caranya sendiri untuk mengekspresikan pengalaman dan kemendalaman religiusitas mereka. ${ }^{55}$ Gagasan, pemberian saran, menceritakan pengalaman, ngrasani (bergosip), ataupun mempergunjingkan sesuatu menampakkan medan perjumpaan pikiran dan perasaan. Keakraban dari hati ke hati terbangun. Jalinan persaudaraan makin erat.

Demikianlah seyogyanya karya membumikan Kabar Gembira di tanah Asia dilaksanakan. Masuknya bukan lagi melalui perdagangan atau menumpang birokrasi penjajahan melainkan murni dari perjumpaan. Dialog tiga lapis (agama-agama, keberagaman budaya, serta kemiskinan) menjadi arena dalam mana Injil itu diwartakan. Gereja pun hadir menebarkan benih iman di Asia. Mengakarkan nilai-nilai Kristiani secara peka zaman serta keadaan. Proses dialog seperti kerja bakti. Melibatkan banyak orang dengan berbagai latar belakang untuk menghasilkan kekhasan iman Kristiani yang tak melulu berkiblat pada 'Barat'.

Dalam konteks Umat Katolik-Tionghoa di Semarang, Gereja perlu memupuk rasa percaya diri Umat Katolik-Tionghoa agar mereka bangga terhadap identitas mereka menjadi Katolik sekaligus Tionghoa. Bangga terhadap jati diri inilah yang kiranya menjadi modal untuk membuka diri pada dialog dan berbaur secara alamiah melalui peran, keterlibatan, dan kekhasan budaya yang tentu berguna bagi kegiatan Gerejani maupun pengembangan masyarakat. Joseph Ratzinger atau dikenal dengan Paus Benediktus XVI mengungkapkan bahwa pembaruan selalu membutuhkan aspek kemartiran dan derita yang di dalamnya termuat kegembiraan sejati akan keselama$\tan ^{56}$ Melalui kerjasama dengan Gereja, Umat Katolik-Tionghoa diajak untuk menjadi garam dan terang bagi dunia melalui sesama. Itu berarti membuka pintu dialog 
dan relasi dengan yang lain sekaligus bersama yang lain membangun kerjasama dalam kesetiaan akan Allah untuk membangun dunia. Langkah dialog tersebut diletakkan dalam upaya kesatuan, perdamaian, serta perjuangan demi pembelaan martabat pribadi manusia. $^{57}$

Menghadapi adanya isu terorisme yang kadang digunakan oleh beberapa kaum fundamentasi sebagai cara 'berjihad', Umat Katolik sebaiknya melakukan martyria dengan semangat dan cara yang sebaliknya, yakni dengan memegang teguh prinsip 'nonviolence'. Semangat martyria Umat Katolik harus tetap dijauhkan dari keinginan untuk melalukan balas dendam. ${ }^{58}$ Menerjemahkan prinsip anti-kekerasan dalam kehidupan bersama berarti pula menjaga tutur kata dan ketulusan hati untuk saling bertegur sapa dengan yang lain. Upaya ini bisa diwujudkan dengan memupus stereotip dan menepiskan kecurigaan kepada sesama. Dengan cara pandang yang lebih positif untuk menilai yang lain, kiranya dialog berjalan dengan lebih optimal serta jalinan kerja-sama yang melahirkan persaudaraan dengan siapa saja yang berkehendak baik dapat terjalin makin erat.

\section{Mengembangkan Semangat Solidaritas, Mewujudkan Diakonia}

Diakonia merupakan serapan langsung dari bahasa Yunani yang artinya pelayanan. ${ }^{59}$ Melalui tugas ini, Gereja menyadari kehadirannya untuk pelayanan masyarakat. Gereja dibangun bukan untuk diri sendiri melainkan berkerja sama dengan yang lain bagi kepentingan bersama. Karya pelayanan Gereja bagi dunia sangatlah penting karena menjadi bagian dari perwujudan iman. Titik tolak diakonia mengacu kepada pola perutusan Kristus yang datang bukan untuk dilayani melainkan melayani. Dengan demikian, Umat Katolik juga diharapkan dapat menampakkan cintakasih Kristus yang menjiwai diri mereka. ${ }^{60}$

Dalam kiprah Gereja mengakurkan tiga dimensi dasar kehidupan dialog Gereja Asia, makna kerukunan haruslah digali lebih dalam. Hidup rukun menjadi corak kehidupan kekatolikan dengan memaparkan segala hal mengenai kebebasan beragama, mengekspresikan segala macam budaya lokal, serta bahu-membahu mengentaskan kemiskinan. Gereja menyadari tentang keluhuran benih-benih Ilahi yang telah ditanam dalam tatanan peri kehidupan manusia. Kristianitas hendaknya dapat bekerja sama membangun persaudaraan sejati dengan setiap pribadi -entah apapun agama, latar belakang budaya, serta golongan mereka- guna mencapai kebebasan berkeyakinan, toleransi, kesejahteraan bersama dan menjunjung keagungan martabat manusia. ${ }^{61}$

Gereja Katolik pun bertanggung jawab untuk mewujudkan Kerajaan Allah di tanah Indonesia. Kehidupan Iman Katolik yang bersumber dari Kitab Suci, tradisi, dan Magisterium perlu ditampakkan dalam wajah-wajah masyarakat dari Sabang sampai Merauke. Kabar Gembira akan Yesus Kristus perlulah dibumikan melalui kesaksian Kristiani dengan penuh cinta kasih dan damai sejahtera. Adanya unsur cinta kasih berarti dalam ranah misinya Gereja Katolik Indonesia ditantang untuk penuh kelembutan, kecerdasan akal budi serta kejernihan hati nurani dalam menyelesaikan masalahmasalah falsafah kehidupan, perbedaan keyakinan keagamaan, berlainan cara pandang kebudayaan, isu-isu politik, ekonomi, serta mengakurkan setiap golongan yang ada. $^{62}$

Upaya dan cita-cita itu tentu tidak mudah karena Umat Kristiani di Indonesia -dan negara-negara Asia pada umumnyabukanlah kelompok mayoritas. Dalam negara yang menghargai pluralisme dan multikulturalisme, sebenarnya tabu dalam menyebut 'mayoritas-minoritas'. Idealnya, dua kutub itu sudah melebur dalam wadah kesatuan Republik Indonesia. Namun, faktanya gambaran ideal masih perlu diperjuangkan. Menjadikan solidaritas sebagai pondasi dari struktur kehidupan sosial masih menjadi 'Pekerjaan Rumah' yang besar. Dengan penuh seksama marilah kita jujur, sindrom 'mayoritas-minoritas' ini tetaplah menjadi isu hangat dalam masyarakat Indonesia apalagi bagi Etnis Tionghoa 
yang beragama Katolik; bisa jadi dirasakan pula oleh umat non-Muslim pada umumnya.

Dalam mewujudkan solidaritas lebihlebih untuk Umat Katolik-Tionghoa di Semarang, Gereja mengembangkan tugas untuk membuka jaringan seluas-luasnya melalui dialog di segala lini kehidupan, terutama keberagaman agama dan budaya serta kemiskinan. Umat Katolik-Tionghoa perlu dilibatkan dalam setiap acara silaturahmi dan bidang-bidang pelayanan masyarakat baik dengan antar Umat Gereja sendiri, agama-agama lain, masyarakat pada umumnya, serta birokrasi pemerintahan. Dengan demikian nampaklah wajah Gereja sebagai pelopor solidaritas yang merengkuh, menjembatani, serta menggerakkan masyarakat luas guna seiring-sejalan mewujudkan kesejahteraan bersama.

Baik Gereja maupun negara mempunyai wewenang untuk memutuskan sesuatu. Dua lembaga ini mempunyai konteks kedaulatan masing-masing meskipun saling terkait satu dengan yang lainnya melalui rasionalitas otonom dalam pemerintahan. ${ }^{63}$ Untuk menampakkan nilai-nilai Kristiani yang berdasarkan cinta kasih, Gereja perlu masuk dalam dunia politik dengan menyumbangkan orang-orang terbaik yang jujur, mampu berpikir secara rasional dan tajam mengasah hati nurani. Selain itu, para pejabat Gereja juga wajib memberikan wawasan secara seimbang tentang keprihatinan-keprihatinan Gereja agar karya pelayanan Gereja menjadi tepat sasaran.

\section{KESIMPULAN}

Panorama rukun hidup Katolik di Asia memaparkan keragaman yang sungguh indah berkat asal-mula dan perkembangan historis mereka. Lagi pula aneka tradisitradisi rohani dan liturgi dalam pelbagai ritus begitu mendayai geliat Gereja Asia. ${ }^{64} \mathrm{Di}$ belahan bumi terluas ini, Gereja menghadapi sekian banyak tantangan falsafi, teologis, dan pastoral. Sebagai yang minoritas di Asia -kecuali di Filipina- Gereja tertantang untuk mengindahkan dambaan Umat dalam hal merasakarasakan serta mengimani Kristus Sang Penyelamat secara khas sesuai dengan citarasa Asia. Maka,
Kristianitas dihayati dengan penuh rasa damai dan rekonsiliasi.

Dalam pergulatan hibriditas yang menghasilkan pribadi baru, saya rasa bukan saatnya lagi untuk meratapi generasi-generasi muda yang lupa akan tradisi leluhur mereka. Pengenalan terhadap tradisi leluhur memang diperlukan akan tetapi yang lebih penting dan mendesak ialah menanamkan nilai-nilai luhur dari setiap ritus serta kebudayaan yang ada. Keutamaan serta perihidup dari integrasi antara budaya dan agama lebih dibutuhkan untuk memerangi krisis moral, kriminalitas, terorisme, ekslusifisme, ketidakadilan, konflik SARA (suku, agama, ras, dan antar golongan), ekploitasi alam, dan kemiskinan.

Alangkah bijaksana bila modernitas dipandang sebagai kekuatan ketimbang momok yang melahirkan degradasi nilai keagamaan dan budaya. Generasi muda Katolik-Tionghoa bisa jadi lebih kreatif dalam mengkombinasikan unsur-unsur religiusitas dan kebudayaan asalkan mendapat pendampingan spiritual dari 'penatua' mereka. Tugas dari para pendahulu dewasa ini ialah lebih menekankan pada mendidik kebajikan yang mengarahkan pada kekhasan tata kehidupan dari semangat persaudaraan, penghormatan kepada leluhur dan alam semesta, mengangkat martabat manusia, mengenalkan pada prioritas publik, kejujuran, serta nilai kasih yang mendasari perbuatan. Kekuasaan masa lalu yang menghasilkan generasi rabun pada kebudayaan leluhur tidaklah melulu dianggap sebagai ancaman. Masih ada harapan ke depan untuk membangun angkatan muda yang makin berkarakter sebab mampu menyilangkan keutamaan agama dan budaya dengan lebih inovatif di era serba digital, sesuai konteks lokalitas dan perkembangan zaman.

Khususnya dalam konteks Umat KatolikTionghoa, antara Gereja dan budaya Tionghoa membutuhkan sikap dan semangat saling mendengarkan, memahami, dan mempelajari. Gereja pun perlu rendah hati memperdalam konteks kehidupan religius sebagai bagian dari pusaka rohani orangorang Tionghoa yang kurang lebih sehati- 
sepikir dengan alam religiusitas Asia. Mereka rela mendengarkan sosok-sosok yang memiliki intuisi agama dan berbicara dengan pengurapan spiritual; bukan sekedar fanatik yang berpikiran sektarian atau picik. Ada penghormatan tinggi pada simbolsimbol Yang Ilahi; peziarahan ke tempat suci, aneka ritual, kidung, kebiasaan, tradisi, benda-benda rohani, ajaran, hukum, mencintai keheningan dan penyangkalan diri. Pola laku batin inilah yang sekiranya bisa menjadi gambaran untuk masuk pada ranah spiritual Umat Katolik-Tionghoa.

Rasa kebersamaan sangat dihargai di Asia. Konghucu mengajarkan solidaritas mutlak dalam keluarga dengan menandaskan "Ketika para saudara hidup rukun dan damai, maka untaian harmoni tidak akan berhenti." ${ }^{65}$ Ikatan kekeluargaan bangsa Tionghoa sangatlah kuat sebab nilai penghormatan akan leluhur berurat-berakar dan diwariskan turun-temurun. Mereka sangat menghormati orang tua, merawat para lansia, dan menghidupi pola kepemilikan bersama. Etika saling tolongmenolong dalam ikatan familiaritas amat kuat sehingga menghasilkan rukun hidup komunitarian yang sambung dengan semangat persaudaraan dalam Gereja.

Memang sebagian besar masyarakat Tionghoa sukar dilepaskan dari aneka upacara dan adat kebiasaan terutama perihal persembahan-persembahan kepada leluhur. Akan tetapi, semua itu lebih sebagai semacam sopan-santun. ${ }^{66}$ Mengindahkan tradisi ialah bagian dari cara hidup, kesetiaan, serta kewajiban. Yang Adi Kodrati seringkali dikaitkan dengan leluhur pula. Nampak dalam wawancara yang saya alami, mereka menyebut dewa-dewi sebagai Kong Co dan Mak Co atau kakek dan nenek buyut. Semangat penghormatan ini melahirkan kesempurnaan jiwa manusia sebab mereka mampu mengatur kelakuan pribadi dan

\section{CATATAN AKHIR}

Bicara dengan gaya keras menggertak

Dalam kebudayaan Jawa, ada tiga tataran berkomunikasi. Pertama, semu mentri. Selalu memalingkan muka saat bertemu. Kedua, esem bupati. Menyampaikan pernyataan secara implisit agar menjadi baik dalam keluarga, masyakarat dan hidup keagamaan. Kalau setiap orang menjalankan kewajibannya dengan kewajiban sosialnya, dengan sendirinya mereka menjadi baik. Hal ini merupakan hubungan timbal balik. ${ }^{67}$ Dunia diciptakan baik dan harus dipelihara dengan baik sehingga moralitas dipandang lebih penting daripada agama.

Berhadapan dengan tradisionalisme klasik masyakarat Tionghoa ini, Gereja mampu belajar untuk menentukan kesatuan prinsip moral yang menggerakkan perbuatan yakni keutamaan untuk hidup baik dengan menjalankan kewajiban dan tanggung jawab pada sesama lagi alam semesta. Pelbagai ritual dan kebudayaan merupakan manifestasi dari upaya ingat akan leluhur, sesama dan lingkungan sekitar. Perkembangan misi selanjutnya ialah bagaimana para klerus, pemimpin pastoral, serta katekis awam mampu mengarahkan dasar penghormatan ini pada keutamaan cinta kasih Kristiani sembari memberikan pendasaran iman untuk menyikapi tentang persembahan dan sesaji.

Gereja mendapat tugas menjadi agen rekonsiliasi di Asia. Ia mengemban perutusan yang memuat imperatif moral untuk memulihkan keintiman antar Allah dengan manusia dan manusia dengan sesama. Begitu banyak konflik yang terjadi akibat peruncingan perbedaan mulai dari suku, agama, ras, antar-golongan, pandangan politik, otoritas pemerintah dan militer, mendesak Gereja lebih sungguh-sungguh mengupayakan rekonsiliasi melalui dialog secara nyata dan terbuka demi konsensus. Tujuannya ialah menghasilkan kembalinya situasi damai sejahtera. Barang tentu, keadaan harmoni ini juga menjadi dambaan Umat Katolik-Tionghoa yang begitu dekat pada kosmologi yin dan yang demi keteraturan alam semesta.

nampak halus. Ketiga, dupak kuli. Tanpa basabasi, langsung menuju maksud dari pesan komunikasi.

3 Adi Ekopriyono, The Spirit of Pluralism; Menggali Nilai-nilai Kehidupan, Mencapai Kearifan (Jakarta: Gramedia, 2005), 25-26. 
4 Misalnya pada Evaluasi di bulan April 2015 tercatat 898 khasus pidana di Semarang selama tiga bulan. Sumber http://jateng.tribunnews.com/2015/04/22/waduh90-hari-terjadi-900-kasus-kriminal-di-kotasemarang diakses tanggal 28 Oktober 2017

5 Yang penting berani, salah atau benar urusan belakangan.

6 Ariel Heryanto, "Kewarganegaraan dan Etnis Cina dalam Dua Film Indonesia Paska-1998," dalam Budaya Populer di Indonesia, ed. Ariel Heryanto (Yogyakarta: Jalasutra, 2012), 110-113.

7 Joel Kuortti \& Jopi Nyman, Recontructing Hybridity; Post-Colonial Studies in Transition, (Amsterdam: Rodopi B.V., 2007), 6.

8 Joel Kuortti and Jopi Nyman, Recontructing Hybridity; Post-Colonial Studies in Transition, 2-3.

9 Homi K. Bhabha, The Location of Culture (London: Routledge, 1994), 9, 30-33.

10 Simon Philpott, Rethinking Indonesia; Postcolial Theory, Authoritarianism and Identity (London: MacMillan Press Ltd., 2000), 61.

11 Bojan Aleksov, "Adamant and Treacherous; Serbian Historians on Religious Converions," dalam Converting Cultures; Religion, Ideology, and Transformations of Modernity, eds. Dennis Washburn \& A. Kevin Reinhart (Leiden: Brill, 2010), 83-86

12 Gaudium et Spes art. 53.

13 Gaudium et Spes art. 56, 57

14 Diserap langsung dari bahasa Yunani yang artinya pewartaan.

15 A. Heuken, Ensiklopedi Gereja. Jilid IV (Jakarta: Yayasan Cipta Loka Caraka, 2005), 177.

16 Pratiwo, "Mencari Semangat Zaman Arsitektur Cina di Indonesia Masa Kini," dalam Masa Lalu dalam Masa Kini; Arsitektur Indonesia. Ed. Peter J.M. Nas (Jakarta: Gramedia Pustaka Utama, 2009), 100-103.

17 Gondomono, Manusia dan Kebudayaan Han (Jakarta: Penerbit Kompas, 2013), 209.

18 Gondomono, Manusia dan Kebudayaan Han, 272275.

19 Amanat Apostolik Evangelii Nuntiandi dari Paus Paulus VI dan juga terdapat pada Nostra Aetate art. 2.

20 E. Armada Riyanto, Dialog Interreligius; Historisitas, Tesis, Pergumulan, Wajah (Yogyakarta: Kanisius, 2010), 118-119.

21 Nio Joe Lan, Peradaban Tionghoa: Selayang Pandang (Jakarta: KPG, 2013), 199-203.

22 Peribahasa Jawa yang artinya menyatukan kembali relasi dalam ikatan kekeluargaan.

23 Nio Joe Lan, Peradaban Tionghoa: Selayang Pandang, 203-205.

24 Disebut Hari Sembahyang atau Ji-kao-kao. Biasanya toko-toko etnis Tionghoa tutup sehari sebelum Imlek untuk sembahyang ini.

25 Nio Joe Lan, Peradaban Tionghoa: Selayang Pandang, 209-215.

26 http://web.budayationghoa.net/index.php/item/325-mengenalciswak-1 diakses tanggal 3 Juli 2017.

27 Gondomono, Manusia dan Kebudayaan Han, 272.
28 Nico Syukur Dister, Teologi Sistematika 2; Ekonomi Keselamatan (Yogyakarta: Kanisius, 2004), 381-383.

29 Octavianus Naif, "Kultur: Cara Spesifik Berada dari Ada," dalam Dialog Antara Iman dan Budaya, (Yogyakarta: Komisi Teologi KWI bekerjasama dengan Yayasan Pustaka Nusatama, 2006), 24-26.

30 Seperti yang terjadi pada Heru Fenas, Vincent Lie, Lena Sindajanti, Gunawan, dan Hendry Suryawibawa.

31 Ernest Maryanto, Kamus Liturgi Sederhana, (Yogyakarta: Kanisius, 2009), 101

32 Koinonia merupakan serapan langsung dari bahasa Yunani yang berarti persektuan.

${ }^{33}$ Al. Purwa Hadi Wardoyo, "Pendampingan Keluarga di Paroki," dalam Gereja yang Melayani dengan Rendah Hati, ed. E. Martasudjita), 162-163.

34 Kata ini diserap oleh bahasa Latin menjadi Ecclesia.

35 Nico Syukur Dister, Teologi Sistematika 2; Ekonomi Keselamatan (Yogyakarta: Kanisius, 2004), 209.

36 Contohnya seperti kelompok-kelompok doa dan kebangunan rohani (Marriage Encounter, Pria Sejati Katolik, Perempuan Berhikmat, Legio Maria, Kelompok Tritunggal Mahakudus, karismatik, CBC), kelompok yang berkaitan dengan mata pencaharian dan keterampilan (Kelompok Pengusaha Katolik, Ikatan Dokter, Jalinan Guru), kelompok dalam kegiatan menggereja (kelompok lektor, misdinar, kelompok koor) atau kelompok yang berbasis etnisitas (ikatan pelajar Papua, Medan, Makassar, Nusa Tenggara, Kalimantan Tengah).

37 M. Nur Widipranoto, "Communio dan Sakramentalitas Gereja; Oase di Tengah Arus Pendangkalan Hidup," 40.

38 Di jantung misteri Gereja berlangsunglah ikatan persekutuan yang menyatukan Kristus Sang Mempelai dengan semua yang dibaptis... Maka tujuan pertama Gereja ialah menjadi sakramen persatuan umat satu dengan yang lain itu berakar dalam persekutuan itu dengan Allah, Gereja merupakan sakramen juga bagi kesatuan umat manusia (Ecclesia in Asia art. 24).

39 Yohanes Paulus II, Gereja di Asia, terj. Dokpen KWI (Jakarta: Dokpen KWI, 2001), 66-67.

40 Yohanes Paulus II, Gereja di Asia, 68.

41 Yohanes Paulus II, Gereja di Asia, 69.

42 Yohanes Paulus II, Gereja di Asia, 69

43 Gaya Semarangan untuk menolak dan berkata tidak.

44 Dewan Karya Pastoral Keuskupan Agung Semarang, Rencana Induk Keuskupan Agung Semarang (RIKAS) 2016-2035 (DKP KAS, 2015), 15-16

45 Frasa ini digunakan pertama kali pada Arah Dasar Umat Allah Keuskupan Agung Semarang atau Ardas 2006-2010. Ardas 2000-2005 memakai frasa persekutuan paguyuban-paguyuban.

46 M. Nur Widi, Eklesiologi Ardas Keuskupan Agung Semarang (Yogyakarta: Kanisius, 2009), 166. 
47 M. Nur Widi, Eklesiologi Ardas Keuskupan Agung Semarang, 165.

48 Berasal dari bahasa Yunani leitourgia. Dibentuk dari kata ergon (karya) dan leitos (akar kata laos yang berarti bangsa).

49 http://www.katolisitas.org/tentang-penghormatankepada-leluhur/ diakes tanggal 1 April 2017.

50 E. Martasudjita, Pengantar Liturgi; Makna, Sejarah dan Teologi Liturgi (Yogykarta: Kanisius, 2006), 79-81.

51 Ernest Maryanto, Kamus Liturgi Sederhana, (Yogyakarta: Kanisius, 2004), 122.

52 Edmund Woga, Misi, Misiologi, dan Evangelisasi di Indonesia (Yogyakarta: Kanisius, 2009), 133135.

53 Eric Reitan, Is God A Delusion; A Reply to Religion's Cultured Despires (West Sussex: WileyBlackwell), 9, 23-26.

54 Robert J. Schreiter, Rancang Bangun Teologi Lokal (Jakarta: BPK Gunung Mulia, 2008), 13-29.

55 Raymundus Sudhiarsa, "Iman dan Budaya dalam Agenda Misi Gereja," dalam Dialog Antara Iman dan Budaya (Jakarta: Komisi Teologi Konferensi Waligereja Indonesia dan Yayasan Pustaka Nusatama, 2006), 123.

56 Kripurwana Cahyadi, Benediktus XVI (Yogyakarta: Kanisius, ), 435.

57 Kripurwana Cahyadi, Benediktus XVI, 434-436.

58 Al. Purwa Hadiwardoyo, "Pendampingan Keluarga di Paroki," dalam Gereja yang Melayani dengan Rendah Hati, ed. E. Martasudjita (Yogyakarta: Kanisius, 2009), 164.

59 Ernest Maryanto, Kamus Liturgi Sederhana, 39.

60 A. Heuken, Ensiklopedi Gereja. Jilid II (Jakarta: Yayasan Cipta Loka Caraka, 2004), 60.

61 Carl Anderson, A Civilization of Love; What Every Catholic Can Do to Transform the World (New York: HarperCollins Publishers, 2009), 12.

62 Carl Anderson, A Civilization of Love; What Every Catholic Can Do to Transform the World, 146.

63 Simon Philpott, Rethinking Indonesia; Postcolonial Theory, Authoritarianism and Identity, 9192.

64 Yohanes Paulus II, Gereja di Asia, 24-25.

65 Thomas Menamparampil, "Nilai-Nilai Asia bagi Bangsa Manusia", dalam Menerobos Batas-Merobohkan Prasangka, eds. Paul Budi Kleden dan Robert Mirsel (Maumere: Penerbit Ledarero, 2011), 41-43.

66 Tom Jacobs, Paham Allah (Yogyakarta: Kanisius, 2002), 100

67 Hukum ini disebut juga dengan reproksitas atau Chinese golden rule.

\section{DAFTAR RUJUKAN}

Aleksov, Bojan. "Adamant and Treacherous; Serbian Historians on Religious Conversions", dalam Converting Cultures; Religion, Ideology, and Transformations of Modernity, Dennis Washburn and A. Kevin Reinhart. Leiden: Brill, 2010. 83-86.

Anderson, Carl. A Civilization of Love: What Every Catholic Can Do to Transform the World. New York: Harpercollins Publishers, 2009.

Bhabha, Hokmi K. The Location of Culture. Routledge: London, 1994.

Cahyadi, Krispurwana. Benediktus XVI. Yogyakarta: Kanisius, 2010.

Dister, Nico Syukur. Teologi Sistematika 2: Ekonomi Keselamatan. Yogyakarta: Kanisius, 2004.

Dokumen Sidang Konsili Vatikan II, diterjemahkan oleh R. Hardawiryana, SJ, Jakarta: Dokpen KWI-Obor, 2004.

Ekopriyono, Adi. The Spirit of Pluralism: Menggali Nilai-nilai Kehidupan, Mencari Kearifan. Jakarta: Gremedia, 2005.

Gondomono. Manusia dan Kebudayaan Han. Jakarta: Penerbit Kompas, 2013.

Heryanto, Ariel. "Kewarganegaraan dan Etnis Cina dalam Dua Film Indonesia Paska-1998", dalam Budaya Populer di Indonesia, ed. Ariel Heryanto. Yogyakarta: Jalasutra, 2012. 110-113.

Heuken, A. Ensiklopedi Gereja. Jakarta: Yayasan Cipta Loka Caraka, 2005. 
http://jateng.tribunnews.com/2015/04/22/w aduh-90-hari-terjadi-900-kasuskriminal-di-kota-semarang diakses tanggal 28 Oktober 2017.

http://www.katolisitas.org/tentangpenghormatan-kepada-leluhur/ diakes tanggal 1 April 2017.

http://web.budayationghoa.net/index.php/item/325mengenal-ciswak-1 diakses tanggal 3 Juli 2017.Jakobs, Tom. Paham Allah, Yogyakarta: Kanisius, 2002.

Kuortti, Joel dan Jopi Nyman. "Introduction: Hybrity Today', dalam Reconstructing Hybridity; Post-Colonial Studies in Transition, ed. Joel Kuortti dan Jopi Neyman. Amsterdam: Rodopi B.V., 2007. 2-6.

Maryanto, Ernest. Kamus Liturgi Sederhana. Yogyakarta: Kanisius, 2009.

Martasudjita, E. Pengantar Liturgi; Makna, Sejarah dan Teologi Liturgi. Yogyakarta: Kanisius, 2006.

Menamparampil, Thomas. "Nilai-Nilai Asia bagi Bangsa Manusia", dalam Menerobos Batas - Merobohkan Prasangka, eds. Budi Kleden, Paul dan Robert Mirsel, Maumere: Penerbit Ledarero, 2011, 41-43.

Naif, Octavianus. "Kultur: Cara Spesifik Berada dari Ada", dalam Dialog Antara Iman Dan Budaya. Komisi Teologi KWI. Yogyakarta: Komisi Teologi KWI bekerjasama dengan Yayasan Pustaka Nusatama, 2006. 2446.

Nio Joe Lan, Perabadan Tionghoa: Selayang Pandang. Jakarta: KPG, 2013.
Philpott, Simon. Rethinking Indonesia; Post-colonial Theory, Authoritarianism and Identity. London: Macmillan Press Ltd., 2000.

Pratiwo. "Mencari Semangat Zaman Arsitektur Cina di Indonesia Masa Kini," dalam Masa Lalu dalam Masa Kini; Arsitektur Indonesia, ed. Peter J.M. Nas. Jakarta: Gramedia Pustaka Utama, 2009. 100-103.

Reitan, Eric. Is God A Delusion; A Reply to Religion's Cultured Desires. West Sussex: Wiley-Blackwell, 2009.

Riyanto, Armada E. Dialog Interreligius; Historisitas, Tesis, Pergumulan, Wajah. Yogyakarta: Kanisius, 2010.

Schreiter, Robert J. Rancang Bangun Teologi Lokal. Jakarta: BPK Gunung Mulia, 2006.

Sudhiarsa, Raymundus. "Iman dan Budaya dalam Agenda Misi Gereja," dalam Dialog Antara Iman dan Budaya, Komisi Teologi Konferensi Waligereja Indo-nesia, Jakarta: Komisi Teologi Konfe-rensi Waligereja Indonesia dan Yayasan Pustaka Nusatama, 2006. 123.

Woga, Edmund. Misi, Misiologi dan Evangelisasi di Indonesia. Yogyakarta: Kanisius, 2009.

Widipranoto, M. Nur. "Communio dan Sakramentalitas Gereja: Oase di Tengah Arus Pendangkalan Hidup," dalam Agiornamento; Pembaruan Hidup Gereja dalam Terang Konsili Vatikan II, ed. Dewan Karya Pastoral Keuskupan Agung Semarang. Yogyakarta: Kanisius, 2013. 38-40.

Yohanes Paulus II, Gereja di Asia: Anjuran Apostolik Sinodal, New Delhi 6 September 1999, diterjemahkan oleh R. Hardawiryana, Jakarta: Dokpen KWI-Mardi Yuana, 2000. 
